\title{
Characterization of the OSSN Microbiome in HIV-1 Infected Patients
}

\author{
Kenneth O. Simbiri ${ }^{1} \&$ Erle S. Robertson ${ }^{1}$ \\ ${ }^{1}$ University of Pennsylvania, Perelman School of Medicine, USA \\ Correspondence: Erle S. Robertson, PhD, Department of Microbiology, Abramson Cancer Center, Tumor \\ Virology Program, Perelman School of Medicine at the University of Pennsylvania, 202A Johnson Pavilion, \\ 3610 Hamilton Walk, Philadelphia, PA 19104-6076, USA. Tel: 215-746-0114. Fax: 215-746-0115. E-mail: \\ erle@mail.med.upenn.edu
}

Received: March 15, 2012 Accepted: March 28, 2012 Online Published: May 1, 2012

doi: $10.5539 /$ cco.v $1 \mathrm{n} 1 \mathrm{p} 88$

URL: http://dx.doi.org/10.5539/cco.v1n1p88

This work was supported by the UPENN Center for AIDS Research (P30-A1455008 to JH) and the Botswana UPENN partnership in Gaborone, Botswana; Public Health awards from the National Cancer Institute of the National Institutes of Health (CA137894, CA138434, CA72150, CA91792, CA91792-S1, CA91792-S2, CA108461 to ESR); the National Institute of Allergy and Infectious Diseases (A167037 to ESR) and the National Institute of Dental and Craniofacial Research (DE17338 to ESR)

\begin{abstract}
Purpose: Ocular surface squamous neoplasia (OSSN) is a rare cancer previously seen in elderly men. In Botswana there is an increase in OSSN and pterygia among young HIV-1 infected patients. Factors that determine the course of this cancer have not been characterized. Recent studies identified HPV, EBV, KSHV, HSV-1/2, and CMV in patient samples. We now characterize the microbiome associated with the disease that may contribute to its course. Results: Pyrosequencing identified viruses, bacteria, fungus and parasites. Analysis of shotgun cloning sequences showed a majority of infectious agents identified by pyrosequencing. Conclusion: HIV patients with OSSN in Botswana are infected with a range of infectious agents which may represent a unique microbiome. The persistent expressions of gene products by these agents some of which are oncogenic are likely to contribute to the oncogenic process and suggest that treatment modalities of the cancer should involve the screening for endemic agents.
\end{abstract}

Keywords: OSSN, pterygium, HIV-1, microbiome, shotgun cloning, pyrosequencing

\section{Introduction}

Ocular surface squamous neoplasia (OSSN) is a conjunctival or corneal neoplastic growth that encompasses the conditions of simple dysplasia to conjunctival intraepithelial neoplasia (CIN) to invasive squamous cell carcinoma (Kiire \& Dhillon, 2006). Similar to cancer of the cervix, it has a relatively high rate of recurrence after treatment and may metastasize (Munoz et al., 2003). OSSN has gained interest in the past few years in its association with the HIV-1 pandemic and its increase in incidence is collinear with the increase in HIV-1 (Mahomed \& Chetty, 2002). Prior to the HIV-1 pandemic, OSSN was noted to occur predominantly in the elderly for whom it is the third most common oculoorbital tumor after melanoma and lymphoma (Basti \& Macsai, 2003; Lee \& Hirst, 1997). Previously in addition to advanced age and male sex, other risk factors linked to its pathogenesis had included ultraviolet light B rays and mutation of the p53 tumor suppressor gene (Kestelyn, Stevens, Ndayambaje, Hanssens, \& van de Perre, 1990), immunosuppression in organ transplant recipients (Spitzer et al., 2008), cigarette smoking, and in some settings, HPV infection (Mahomed \& Chetty, 2002; McDonnell, McDonnell, Mounts, Wu, \& Green, 1986). In Africa, OSSN is becoming more common, more aggressive and affects mainly young people, especially females (Kestelyn et al., 1990).

In addition to OSSN and pterygia, some of the AIDS-related ocular lesions that are associated with viruses include cytomegalovirus retinitis, conjunctival Kaposi's sarcoma, herpes zoster ophthalmicus, retinal toxoplasmosis, choroidal Pneumocystis carinii infection, herpes simplex and herpes zoster retinitis, and cryptococcal choroiditis (Verma \& Kearney, 1996).

Schistosome parasites have been shown to be associated with cancer, and more specifically Schistosoma hematobium can cause bladder cancer (Anastos, Hoover, Burk, et al., 2010). Chen and Mott observed that the 
endemicity of the parasite supports association of bladder cancer with schistosomiasis (Chen \& Mott, 1989). They also noted that the incidence of bladder cancer in the Middle East and Africa is greater in areas with higher Schistoma prevalence and less in areas with lower prevalence (Chen \& Mott, 1989). They noted that in tumor cases the expression of p53, bcl-2, c-myc, and EGFR was higher in schistosomal bladder tumors (SBT) than in non schistosomal bladder tumors (NSBT) while Rb was higher in NSBT than SBT, and that Cyclin D1 was expressed in $57.5 \%$ of tumors, and was associated with schistosomiasis and early stage well differentiated cancers (Anastos et al., 2010).

Fasciola hepatica (F.hepatica) also known as sheep liver fluke disease, is common in sheep and other domestic livestock (Bunnag, Cross, \& Bunnag, 2000). Human infection can occur from ingesting watercress in sheep raising areas (Bunnag et al., 2000). The life span of adult F. hepatica is between 9 and 13 years. In addition to hepatic parenchymal necrosis and abscess formation from migrating larvae, adult flukes cause hyperplasia, thickening, desquamation and dilatation of the bile ducts (Bunnag et al., 2000). The oncogenic potential of $F$. hepatica remains unproven at present, with a portion of the available evidence being contradictory. Experimental data supports two opposite effects, that is, tumor growth stimulating and tumor growth inhibiting (Sriurairatana, Tengchaisri, \& Sirisinha, 1996).

Malaria has also been implicated in cancer. In a recent study Anastos et al. reported higher risk in CIN3+ HIV+ women in Rwanda who had recently acquired the malaria parasite (Anastos et al., 2010). Co-infection with malaria in HIV-1 patients dysregulates the immune system (Bebell, Pilcher, Dorsey, et al., 2010). Bebell et al. observed that acute HIV-1 infections occurred in high HIV prevalence regions of Uganda with low malaria endemicity (Bebell et al., 2010). Kelly and Rickinson in their review of Burkitt's lymphoma pathogenesis emphasized the significance of HIV-1 and malaria (Kelly \& Rickinson, 2007).

Though bacteria are the most abundant in the microbiome, not many of them have been associated with cancer. However, studies now show a direct association of Helicobacter pylori with gastric adenocarcinoma (Lee \& Moss, 2007; Peek \& Blaser, 2002; Blaser, Perez-Perez, Kleanthous, Cover, et al., 1995; Peek \& Blaser, 2002), and Bacteroides fragilis with colorectal carcinoma (Sears, 2009; Kim, Lee, \& Kim, 2008). Additionally, fungal toxins such as aflotoxins from Aspergillus flavus and Aspergillus parasiticus have been associated with liver cancer (Kew, 2003).

These studies suggest the contribution of viruses, bacteria, fungi, and parasitic infections in initiation and maintenance of these cancers. The identification of the known oncogenic viruses HPV, KSHV, and EBV in OSSN and pterygia tissues suggests that they may contribute to the development of this malignancy in the HIV-1 infected population (Simbiri, Murakami, Feldman, et al., 2010). The aim of this study was to obtain a more comprehensive identification of the associated microbiome in patients with OSSN in the HIV-1 infected population in Botswana. The significance of microbes in cancer initiation and maintenance cannot be emphasized enough when the many processes they can influence are considered (Table 1). 
Table 1. Microbial processes associated with cancer initiation

\begin{tabular}{|c|c|c|c|}
\hline Mechanism & Microbe & Cancer & Reference \\
\hline \multirow[t]{3}{*}{ DNA repair } & H.pylori & Gastric adenocarcinoma & PlOS Pathogens (2010) 6 (7) \\
\hline & S.mansoni & Colorectal carcinoma & Int J Colorectal Dis (2007) 22:175-181 \\
\hline & O.viverrini & Cholangiocarcinoma & Parasit Intern.(2012) 61:130-135 \\
\hline \multirow[t]{5}{*}{ Proliferation } & H.pylori & Gastric adenocarcinoma & Expert Opin Ther Targets (2007):11(6)757-769 \\
\hline & S.bovis & Colorectal carcinoma & Carcinogenesis(2004)25(8):1477-84 \\
\hline & S.haematobium & Bladder cancer & Mutat Res. (1994) 305:283-292 \\
\hline & O.viverrini & Cholangiocarcinoma & Int. J. Cancer (1991), 48:821-825 \\
\hline & B.fragilis & Colorectal carcinoma & Clin Microbiol Rev. 2009 Apr;22(2):349-69 \\
\hline \multirow[t]{2}{*}{ Apoptosis } & S.bovis & Colorectal carcinoma & Carcinogenesis(2004)25(8):1477-84 \\
\hline & B.fragilis & Colorectal carcinoma & Eur. J. Immunol. 2008. 38: 2190-2199 \\
\hline \multirow[t]{2}{*}{ Differentiation } & S.haematobium & Bladder cancer & Cancer Res. 1994 Apr 1;54(7 Suppl):1929s-1933s \\
\hline & H.pylori & Stomach & Nat Rev Cancer 2002;2:28-37 \\
\hline \multirow[t]{3}{*}{$\begin{array}{l}\text { Carcinogen } \\
\text { metabolism }\end{array}$} & A flavus & Liver carcinoma & Liver International (2003)23 (6):405-409 \\
\hline & S.haematobium & Bladder cancer & Cancer Res. 1994 Apr 1;54(7 Suppl):1929s-1933s \\
\hline & H.pylori & Gastric adenocarcinoma & Carcinogenesis(2004)25(8):1477-84 \\
\hline \multirow[t]{5}{*}{ Inflammation } & H.pylori & Gastric adenocarcinoma & Cancer Res 1995;55:2111-5 \\
\hline & S.bovis & Colorectal carcinoma & Carcinogenesis(2004)25(8):1477-84 \\
\hline & B.fragilis & Colorectal carcinoma & Clin Microbiol Rev. 2009 Apr;22(2):349-69 \\
\hline & C. sinensis & Liver carcinoma & Parasit Intern.(2012) 61:130-135 \\
\hline & C. sinensis & Liver carcinoma & Parasit Intern.(2012) 61:130-135 \\
\hline \multirow[t]{3}{*}{ Immune function } & H.pylori & Gastric adenocarcinoma & Nat Rev Cancer 2002;2:28-37 \\
\hline & O.viverrini & Cholangiocarcinoma & Int.J. Cancer (1991), 48:821-825 \\
\hline & S.aureas & SCC Skin & $\begin{array}{l}\text { Cancer Epidemiol Biomarkers Prev. (2009) 18(2) } \\
\qquad 472-478\end{array}$ \\
\hline \multirow[t]{3}{*}{$\begin{array}{l}\text { Hormonal } \\
\text { regulation }\end{array}$} & H.pylori & Gastric adenocarcinoma & Nat Rev Cancer 2002;2:28-37 \\
\hline & S.haematobium & Bladder cancer & Experimental Parasitology(2009)130:(2)250-253 \\
\hline & B.fragilis & Colorectal carcinoma & Clin Microbiol Rev. 2009 Apr;22(2):349-69 \\
\hline
\end{tabular}

The table shows pathogens that have been identified with the development of specific human cancers and the mechanistic processes associated with each of the cancers

\section{Research Methods}

\subsection{Patient Samples}

HIV-1 infected patients with conjunctival lesions seen at Princess Marina Hospital, Gaborone, Botswana from April 112007 to April 142008 were enrolled in this study (IRB \#805049 and Ministry of Health, Botswana REF NO: PPME 13/18/1 Vol III 141). All patient diagnosis and enrollment were as described previously (Simbiri et al., 2010). Briefly, patients were identified by an ophthalmologist in the tertiary care ophthalmology clinic at Princess Marina Hospital which serves as the referral center for southern Botswana. All HIV-1 positive patients diagnosed using a HIV-ELISA (Abbott Laboratories, Hoofddorp, the Netherlands) with clinical features suggestive of OSSN or pterygium were enrolled the day before surgery. Written consent was obtained from each subject in either Setswana or English (according to subject's preference). Tissue specimens obtained in the ophthalmology operating room were divided into two pieces by the ophthalmology surgeon - one piece was sent 
for histopathologic analysis and the other was immediately placed in tissue transport medium for shipment to the University of Pennsylvania viral oncology laboratory. Histologic confirmation of each clinical diagnosis was obtained from the Botswana National Health Laboratory's histo-pathologist. 39 patients participated in the study, however tissue samples of varying sizes were obtained from only 36 cases. Tissues from patients included in this study were 30 whose clinical diagnosis was OSSN and 9 with pterygia (Table 2). The research was approved by the University of Pennsylvania ethics committee and adhered to the tenets of the Declaration of Helsinki. Tissue specimens were analyzed by histopathology to determine the stage of the cancer and also further analyzed for identification of the associated infectious agents. Histological confirmation of clinical diagnosis was determined by the University of Pennsylvania resident pathologist.

Table 2. Patient Characteristics

\begin{tabular}{|c|c|c|c|c|c|c|}
\hline \multirow{2}{*}{ Case \# } & \multicolumn{2}{|c|}{ OSSN } & \multicolumn{2}{|c|}{ Pterygia } & \multirow{2}{*}{ P-value } & \multirow{2}{*}{ Odds Ratio } \\
\hline & $\#$ & $\%$ & $\#$ & $\%$ & & \\
\hline Total & 30 & (77) & 9 & (23) & 0.79 & \\
\hline Males & 11 & (37) & 2 & (22) & 0.63 & 1.6 \\
\hline Females & 19 & (63) & 7 & (77) & 0.58 & 0.81 \\
\hline Viral load $<400$ & 13 & (43) & 3 & (33) & 0.56 & 1.3 \\
\hline Viral load $>400$ & 07 & (100) & 0 & $(0)$ & 0.05 & 7.0 \\
\hline Viral load ND & 10 & (33) & 4 & (44) & 0.47 & 0.73 \\
\hline $\mathrm{CD} 4<200$ & 18 & $(60)$ & 2 & (22) & 0.29 & 2.7 \\
\hline $\mathrm{CD} 4>200$ & 07 & (23) & 6 & (67) & 0.91 & 0.3 \\
\hline CD4 ND & 05 & (17) & 1 & (11) & 0.79 & 1.45 \\
\hline ART & 19 & (63) & 5 & (56) & 0.67 & 1.14 \\
\hline ART ND & 11 & (37) & 4 & (44) & 0.69 & 0.81 \\
\hline
\end{tabular}

The table shows patient diagnosis, sex, CD4 counts, viral load, and the retroviral therapy (ART) status of each patient on enrollment. Patients were diagnosed as OSSN or Pterygia clinically and by histology. There were more OSSN with viral load $>400$ copies $/ \mathrm{ml}$, and more pterygia with CD4 counts $>200$ cells $/ \mu$ l. Because of the low number of subjects the P-values based on Fisher's test did not reach significance level except for viral load $>400$ copies $/ \mathrm{ml}$ in which all were OSSN. However, OR from the table shows that males, subjects with viral load $<400$, subjects with viral load $>400$, subjects with $\mathrm{CD} 4<200$, and subjects under Antiretroviral (ART) are more likely to be OSSN than pterygia.

\subsection{Pyrosequencing}

Sera samples were prepared using Whole Genome Amplification Procedure based on Qiagen REPLI-g Midi kit 150043 (Qiagen, Valencia, CA): $200 \mu \mathrm{l}$ of serum were spun down at $6000 \mathrm{xg}$ for $10 \mathrm{~min}$ and supernatant discarded. Pellet was resuspended by adding $50 \mu \mathrm{TE}$ and vortexing for 5 seconds. $10 \mu 1$ denaturation buffer was added to the tubes and mixed $3 \mathrm{X}$ by pipetting and setting on ice for 10 minutes. $10 \mu \mathrm{l}$ Stop Solution was added to each tube containing the lysed cells and mixed by pipetting $3 \mathrm{X}$. Master mix was prepared by mixing $10 \mu \mathrm{l}$ nuclease free water, $29 \mu 1$ REPLI-g Midi reaction buffer, $1 \mu 1$ Repli G Midi DNA polymerase (40 $\mu$ l) and added to each sample.

The samples were incubated at $30^{\circ} \mathrm{C}$ overnight at $65^{\circ} \mathrm{C}$ for 3 minutes then stored at $-20^{\circ} \mathrm{C}$ until use $10 \mu 1$ was sent for pyrosequencing using 454 (454 Life Sciences, Branford, CT) pyrosequencing technique for global detection of foreign sequences expressed in OSSN and pterygia samples.

\subsection{Shotgun Cloning of DNA Extracted from Patient Sera}

We extracted DNA from sera, purified, and then digested with BamH1 restriction enzyme. Briefly, $500 \mu$ l serum was aliquoted into eppendorf tubes and spun at maximum speed of $15,000 \mathrm{rpms}$ at $4^{\circ} \mathrm{C}$ for 30 minutes. The aqueous layer was transferred into new tubes and frozen at $-80^{\circ} \mathrm{C}$ for 1 hour to overnight. The pellet was resuspended with $250 \mu \mathrm{l}$ of $0.2 \mathrm{x}$ PBS. $5 \mu \mathrm{l}$ DNAse and $5 \mu \mathrm{l}$ RNAse was added (from stock of $5 \mathrm{mg} / \mathrm{ml}$ ) and incubated at $37^{\circ} \mathrm{C}$ for $1-2$ hours. $5 \mu$ proteinase- $\mathrm{K}$ was added $(10 \mathrm{mg} / \mathrm{ml}$ stock) and incubated for 20 minutes at 
$56^{\circ} \mathrm{C}$. The samples were further incubated at $96^{\circ} \mathrm{C}$ for 10 minutes. $5 \mu$ Proteinase-K was added and incubated for 1 hour at $56^{\circ} \mathrm{C}$. The samples were incubated at $96^{\circ} \mathrm{C}$ for 30 minutes and volume brought to $500 \mu 1$ with $0.2 \mathrm{X}$ PBS. Using buffered phenol with Tris pH7.5 1:1, samples were extracted $2 \mathrm{X}$ and spun at maximum speed at RT for 5 minutes. The aqueous layer was transferred into new tubes, and an equal volume of chloroform added and mixed. The samples were spun at maximum speed at RT for 5 minutes and transferred to new tubes. $50 \mu 1$ sodium acetate $(3 \mathrm{M})$ was added and an additional $1 \mathrm{ml}$ absolute ethanol was added and incubated $\mathrm{o} / \mathrm{n}$ at $-20^{\circ} \mathrm{C}$. The samples were spun at $4^{\circ} \mathrm{C}$ maximum speed for 15 minutes and aspirated with drawn out Pasteur pipette. The samples were washed $2 \mathrm{X}$ with $1 \mathrm{ml} 70 \%$ ethanol by spinning at maximum speed for 5 minutes at RT. The supernatant was aspirated, air dried and dissolved in $30 \mu \mathrm{l}$ TE. $10 \mu \mathrm{l}$ of the samples were digested with BamH1 restriction enzyme for 3 hours, run on $0.8 \%$ Agarose gel. The bands were extracted, purified and ligated into pBluescript vector (Agilent Technologies, Santa Clara, CA). Some clones were picked, purified in $0.8 \%$ agarose gel and sequenced.

\section{Analysis Result}

3.1 Sequencing of Nucleic Acids from Patient Sera Shows the Presence of Sequences Which Identifies Parasites, Bacteria, Viruses, and Fungi Endemic in Sub-Sahara Region

Table 3. Infectious agents identified in sera samples of patients by shotgun cloning

\begin{tabular}{|c|c|c|c|}
\hline VIRUSES & BACTERIA & PARASITES & FUNGI \\
\hline RNA viruses & Gram negative & Nematodes & $\begin{array}{c}\text { Schizosaccharomyces } \\
\text { pombe }\end{array}$ \\
\hline$H I V-1$ & Klebsiella spp & Dirofilaria immitis & $\begin{array}{l}\text { Sordariomyceta } \\
\text { sordariaceae }\end{array}$ \\
\hline Rous sarcoma virus(RSV) & Pseudomonas spp* & Oncocerca volvulus & Agaricales marasmiaceae \\
\hline Dengue virus type 3 & Salmonella spp* & Trichinella spiralis & $\begin{array}{l}\text { Eurotiomycetes } \\
\text { neosartorya }\end{array}$ \\
\hline Influenza A & Neisseria gonorhoea & C. elegans & $\begin{array}{l}\text { Tremallaceae } \\
\text { filobasidiella }\end{array}$ \\
\hline $\begin{array}{l}\text { Human respiratory syncytial } \\
\text { virus }\end{array}$ & E. coli spp* & Trematodes & \\
\hline DNA viruses & Vibrio spp* & Nemertoderma spp* & \\
\hline Equine herpes virus type 1 & Gram positive & Sterreria spp* & \\
\hline$H H V-4$ & Staphylococcus aureas & Schmidtea polychroa & \\
\hline$H H V-5$ & Mycobacterium spp* & Fasciola hepatica & \\
\hline HHV-6 & Clostridium spp* & Protozoa & \\
\hline$H H V-8$ & Streptococcus spp* & Plasmodium. falciprum & \\
\hline \multirow[t]{6}{*}{$S V-40$} & & Leishmania. chagasi & \\
\hline & & Trypanosoma spp* & \\
\hline & & $\begin{array}{l}\text { Cryptosporadium } \\
\text { hominis }\end{array}$ & \\
\hline & & Parasitic vectors & \\
\hline & & Glossina palpalis & \\
\hline & & Culex spp* & \\
\hline
\end{tabular}

*More than one species detected in samples

Utilizing shotgun cloning method $500 \mu 1$ serum from patients was aliquoted into eppendorf tubes. The samples were spun down at maximum speed for $30 \mathrm{~min}$ at $4^{0} \mathrm{C}$. The pellets were resuspended with $250 \mu 10.2 \mathrm{X}$ PBS. $5 \mu 1$ DNAse and RNAse (5mg/ml stock) were added to each sample and incubated for $1-2$ hours. $5 \mu$ lof proteinase K $\left(10 \mathrm{mg} / \mathrm{ml}\right.$ stock) was added and incubated for $20 \mathrm{~min}$ at $56^{\circ} \mathrm{C}$. Samples were further incubated at $96^{\circ} \mathrm{C}$ for 10 min. $5 \mu$ proteinase $\mathrm{K}$ was again added and incubated for $1 \mathrm{hr}$ at $56^{\circ} \mathrm{C}$ followed by denaturation at $96^{\circ} \mathrm{C}$ for 30 min. The volume was brought to $500 \mu 1$ with $0.2 \mathrm{X}$ PBS. The samples were extracted $2 \mathrm{X}$ using buffered phenol 
with Tris pH 7.5 1:1. Samples were spun down at maximum speed at RT for 5 mins and aqueous layer transferred into new tubes into which equal volume of chloroform was added and mixed well. Samples were spun down again and transferred into new tubes and $50 \mu \mathrm{l}(3 \mathrm{M})$ sodium acetate added. $1 \mathrm{ml}$ absolute ethanol was added and samples were incubated at $-20^{\circ} \mathrm{C}$ overnight. The next day samples were spun down at maximum speed at $4^{\circ} \mathrm{C}$. Ethanol was decanted and $70 \%$ ethanol added and samples spun at maximum speed for 5 min at RT. The supernatant was aspirated and samples were air dried and dissolved in $30 \mu \mathrm{TE}$. We prepared pBluescript vector and patient samples by digesting with BamH1. The inserts were ligated into the vector by using T4 ligase and incubated overnight at $16^{\circ} \mathrm{C}$. Products were used to transform DH5 $\alpha$ competent cells and plated on ampicillin resistant plates overnight. Colonies were selected and DNA was extracted, purified and digested with BamH1 to confirm inserts. The samples were then sent for sequencing. RNA viral, DNA viral, bacterial, parasitic and fungal sequences were identified in the samples. There were more herpestype viral sequences among the identified viruses and more bacterial sequences than all identified pathogenic sequences put together. Fewer fungal sequences were observed.

We cloned DNA from sera samples from patients with OSSN and pterygia. The results showed that the samples contained sequences from a wide range of bacteria, viruses, parasites, and fungi (Table 3). We also detected parasitic vector sequences such as Glossina palpalis and Culex quinquuefasciatus in the samples. The direct association and contribution of some of the parasites and the vector moieties to the overall pathology of the cancer is not known. Interestingly, we observed a greater number of herpes type viruses that have been associated with oncogenesis (McDonnell, 1986; Simbiri et al., 2010; Hoshikawa, Satoh, Murakami, et al. 2002), and bacteria, parasites, and fungi whose co-infection leads to enhanced immunosuppression of the HIV infected host (Lloyd-Smith, Poss, \& Grenfell, 2008; Barnabas, Webb, Weiss, \& Wasserheit, 2011). Fungal S. pombe and the common free living soil nematode C.elegans were also detected. Thus the implication of identifying both parasite and vector, viral, bacterial and fungal sequences in these samples is far reaching in regards to immunosuppression, which may result from this onslaught from multiple infectious agents on the immunocompromised HIV-1 patients.

\subsection{A Greater Number of Infectious Pathogens are Present in OSSN Patients than in Pterygia Patients Infected} with HIV-1

Pyrosequencing of DNA from sera obtained from OSSN and pterygia subjects indicated that patients had been exposed to different infectious agents that may contribute to the pathogenesis of OSSN. Additionally, there were more sequences of bacteria, followed by viruses, and parasites in patients. A majority of the identified pathogenic sequences were higher in the OSSN than pterygium samples (Figure 1,2,3). 


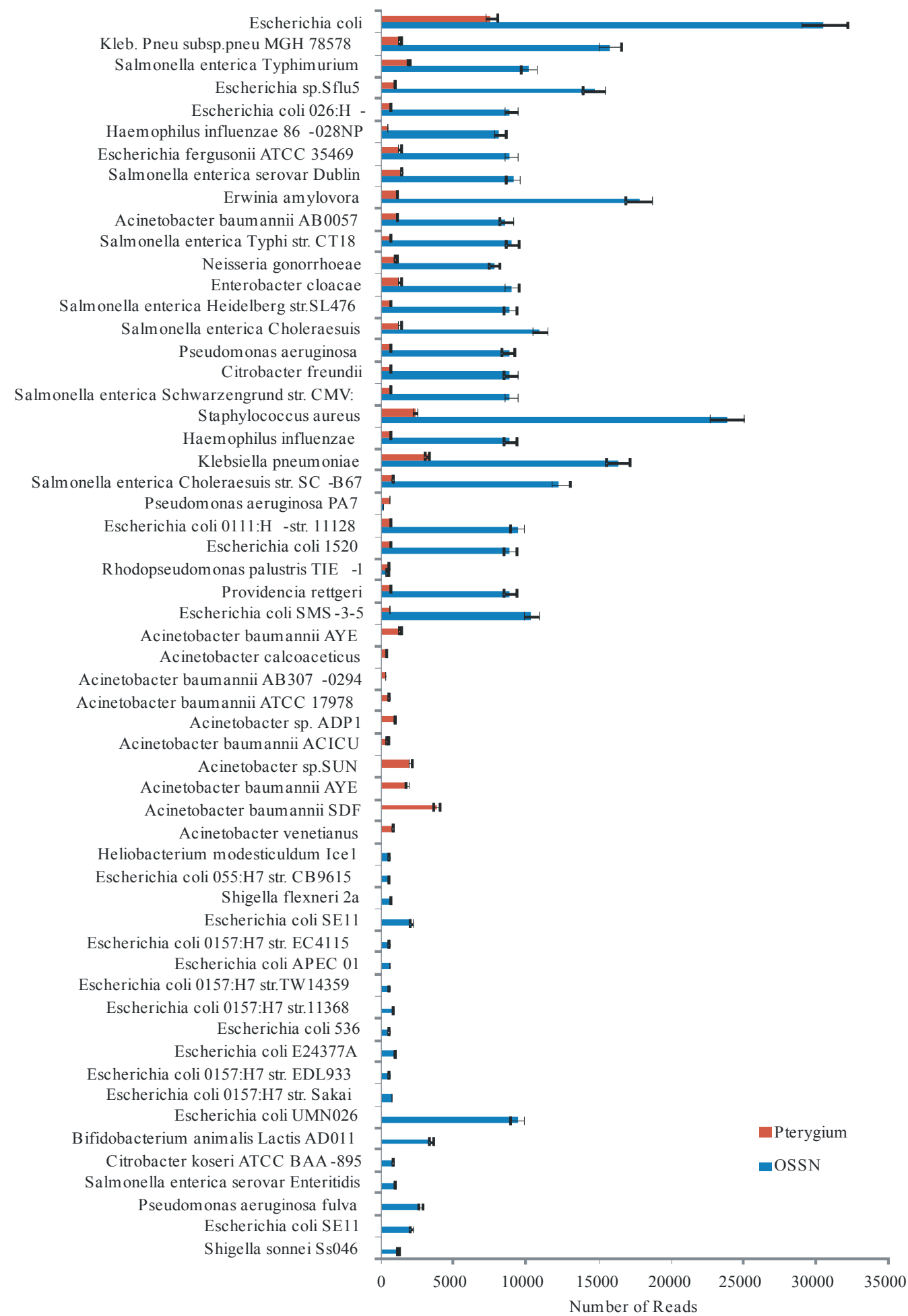

Figure 1. Representative bacterial sequence identified in patient sera

The figure shows the composition of the bacteria identified showing significant number of the bacteria, their species and sub-species in OSSN cases having more sequences and higher reads than pterygia. We also noted that OSSN case had extra E.coli subspecies not detected in pterygium, while pterygium had additional Acinobacter baumannii subspecies missing in OSSN 


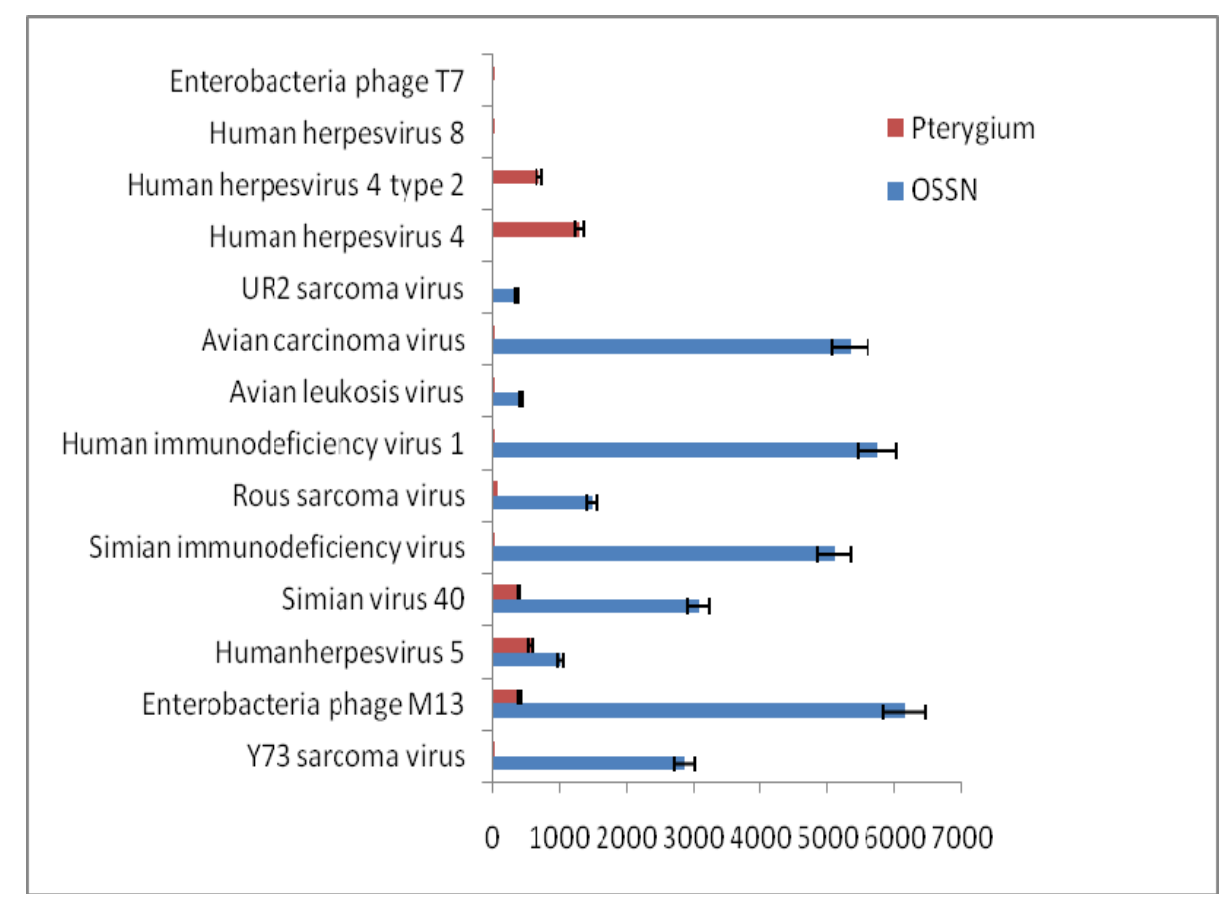

Figure 2. Representative viral sequences identified in patient sera

There were more virus reads for OSSN than pterygia. We observed higher reads for Avian carcinoma virus, HIV-1, SIV, SV-40, Enterobacteria phage M13, and Y73 sarcoma virus than in pterygium.

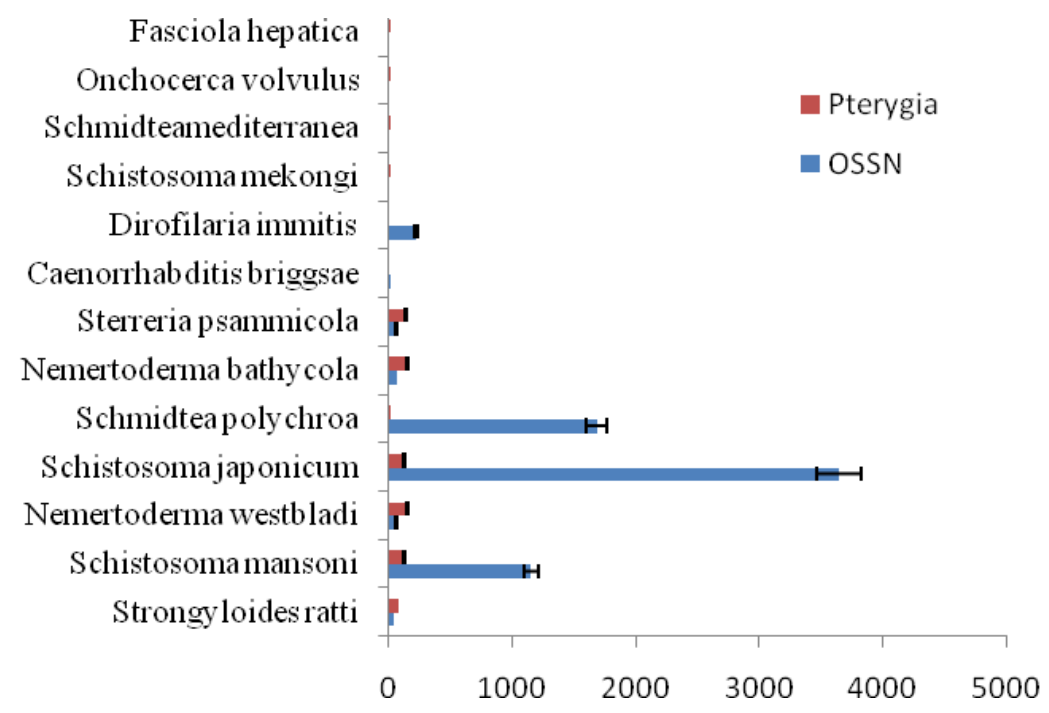

Figure 3. Representative parasite sequences identified in parasite sera

There were more parasite reads for OSSN than pterygia. Specifically we noted higher counts of Schmidtea polychroa, Schistosoma japonicum, and Schistosoma mansoni.

Samples were prepared using Whole Genome Amplification Procedure based on Qiagen REPLI-g Midi kit 150043(Qiagen): $200 \mu \mathrm{l}$ of serum were spun down at $6000 \mathrm{xg}$ for $10 \mathrm{~min}$ and supernatant discarded. Pellet was resuspended by adding $50 \mu \mathrm{T} \mathrm{TE}$ and vortexing for $5 \mathrm{sec} .10 \mu \mathrm{l}$ denaturation buffer was added to the tubes and mixed $3 \mathrm{X}$ by pipetting and setting on ice for $10 \mathrm{~min}$. $10 \mu \mathrm{l}$ Stop Solution was added to each tube containing the lysed cells and mixed by pipetting $3 X$. Master mix was prepared by mixing $10 \mu 1$ nuclease free water, $29 \mu 1$ REPLI-g Midi reaction buffer, $1 \mu 1$ Repli GMidi DNA polymerase $(40 \mu 1)$ and added to each sample. The samples were incubated at $30^{\circ} \mathrm{C}$ overnight. The polymerase in the samples was inactivated by heating at $65^{\circ} \mathrm{C}$ for $3 \mathrm{~min}$ 
then storing at $-20^{\circ} \mathrm{C}$ until use. $10 \mu 1$ was sent for pyrosequencing using 454 (454 Life Sciences, Branford, CT) pyrosequencing technique for global detection of foreign sequences expressed in OSSN and pterygia samples. The sequencer uses parallel pyrosequencing technique to generate about a million bases in $7.5 \mathrm{hrs}$ run with a read of about 250 bases. The uniqueness of this application is that it includes de novo whole genome sequencing supported by paired-end mapping, amplicon resequencing, transcriptome analysis that greatly enhanced detection of foreign sequences in our samples. Using this technique we were able to detect viruses, bacteria, fungi, and parasites.

Of interest was the detection of more gram-negative bacteria compared to gram positive bacteria, specifically those that were present in both OSSN and pterygia, but higher in OSSN than pterygia. Notable were gram negative Neisseria gonorrhea a common sexually transmitted bacteria, and the ubiquitous gram positive nosocomial agent Staphylococcus aureus. Of significance was the observation of several different subspecies of E.coli in OSSN alone and similarly several different subspecies of Acinobacter baumannii in pterygia alone (Figure 1). Of the viruses we were surprised at the level of Avian carcinoma virus, Enterobacteria phage M13, and Y73 sarcoma virus (Figure 2). The parasitic sequences (Figure 3) were interesting because previous studies suggest that some which include S. mansoni and F. hepatica, have been associated with cancer (Chen \& Mott, 1989; Bunnag et al., 2000; Sriurairatana et al., 1996).

Furthermore, OSSN patient who was more immunosuppressed generated a much higher level of infectious agents compared to pterygium patient. Interestingly, there were about a 5-10 fold greater increase in the load of bacteria, parasites and viruses seen in OSSN sample compared to pterygia sample (Figure 1,2,3).

\section{Discussion}

Our study of OSSN tissues from Botswana HIV-1 infected patients has led to significant findings, namely the association of multiple oncogenic viruses with this cancer (Simbiri et al., 2010). In the current study through cloning and pyrosequencing, our results showed sequences of additional viruses, bacteria, fungi, and parasites in the sera of the patients. There is an increasing amount of investigation examining the modifying effect on host susceptibility that one pathogen has on another. Thus many bacterial, viral, and protozoal infections induce protective Th1 cell-mediated immune response in resistant individuals while helminth infections lead to predominantly Th2 skewing of the immune effector cells (Yang, Gray, Ellis, Yang, Craig, McManus, 2009), yet with findings such as ours, little has been done to determine these associations and their effects on the individual and the general exposed population.

To our knowledge this is the first report which demonstrates the co-existence of a significant number of bacteria, viruses, parasites, and fungi in OSSN and pterygia patient samples. Pyrosequencing of DNA extracted from sera of patient samples confirmed early findings based on cloning and sequencing of similar samples, showing that the patients were exposed to many bacteria, viruses, and parasites (by new infections or reactivation of dormant/ latent infections) (Lloyd-Smith et al., 2008), infections that could exacerbate the existing immunocompromised conditions. From our representative samples, it was noted that OSSN patient with CD4 counts of $134 \mathrm{cells} / \mu 1$ and viral load of 120,000 copies /ml was more immunosuppressed having more bacterial, viral and parasitic infections than pterygium patient with CD4 counts of 293 cells $/ \mu 1$ and viral load of $<400$ copies $/ \mathrm{ml}$. The skewed count of E.coli subspecies in OSSN and Acinobacter baumannii subspecies in pterygia may suggest some microenvironmental changes due to stage of the disease and specific microbiota load influencing the growth of these specific bacteria in the specific subjects. These results build support for multiple infection with other agents leading to severe immunosupression from low CD4 cell counts, and chronic stimulation that in addition could lead to tolerance and suppression of the expression of cytokines to lower levels than HIV-negative and OSSN-negative control drawn from the same region. The depletion of $\mathrm{CD}^{+} / \mathrm{CD} 8^{+}$cells and dysfunction of $\mathrm{CD} 8^{+}$ cells that play critical roles in defense against most pathogens, including viruses, and can lead to activation of herpesviruses which are usually latent (Griffin, Krantz, Selke, Huang, \& Wald, 2008; Whitley, Kern, Chatterjee, Chou, \& Roizman, 1993) may play a significant role during the pathogenesis of the disease in these patients. The possibility that oncogenic proteins or immunosuppressive factors from these infectious agents contribute to OSSN pathology is thus suggested. Indirectly infectious agents may contribute to cancer by increasing HIV-1 viral load that leads to more immunosupression thus enhancing oncogenesis and an increase in opportunistic infections (Palefsky, 2009). Barnabas et al reported an increase in HIV-1 viral load with malaria, HSV-2, and tuberculosis infections (Barnabas, Webb, Weiss, \& Wasserheit, 2011). Thus, it is possible that if we have immunocompromised patients who are susceptible and infectious then transmissibility of the infectious agents can be increased to a level that a strain that would die out in HIV-1 negative individual will be able to successfully invade potential hosts and persist. Though our patient cohort was under Antiretroviral Therapy (ART) started at different time points, their effects with regards to these infectious agents that also cause 
immunosupression and some cancers has not been evaluated. It is possible that before ART era AIDS patients died before the appearance of HPV and other HIV associated lesions, and that the prolongation of life now allows the development of these benign and neoplastic lesions (Meys, Gotch, \& Bunker, 2010). There are studies that show that the success of ARTs lowering HIV-1 viral load leads to increased opportunistic infections, some of which are drug resistant (Palefsky, 2009; Croft, Sundar, \& Fairlamb, 2006; Legros, Evans, Maiso, Enyaru, \& Mbulamberi, 1999).

Herrera and Ostrosky-Wegman noted that chronic inflammation in host tissues is a common feature of helminth infections (Herrera \& Ostrosky-Wegman, 2001). The longer the inflammation persists, the higher the risk of associated carcinogenesis. Some of our patients showed increased levels of inflammatory cytokines and growth factors that support Herrera's findings (unpublished data). However, in the experiments we observed decreased expression of several inflammatory cytokines, a factor possibly resulting from the global immunosupression by these infectious agents in an already immunocompromised patient. Some studies have shown that HIV Tat is able to penetrate the intact stratified epithelium of the cornea and wounded cornea, allowing rapid and intense penetration of Tat into the deeper stratified epithelium and stromal tissue (Guo, Hutcheon, \& Zieske, 2004). Thus, the secretion of HIV Tat may lead to its penetration of mucosal epithelial cells leading to activation of NF-kB. HIV-Tat mediated activation of NF-kB may activate latent herpesviruses because most herpesviral promoters have response elements to NF-kB (Santoro, Rossi, \& Amici, 2003). Activation of NF-kB may also lead to the upregulation of HPV oncoproteins, facilitating the progression of HPV neoplastic processes (Ruutu, Peitsaro, Johansson, \& Syrjanen, 2002).

Furthermore, disruption of the corneal epithelium may lead to superinfection with new strains of the viruses thus enhancing oncogenesis (Remeijer, Maertzdorf, Buitenwerf, Osterhaus, \& Verjans, 2002). The opportunistic viruses which we identified in our samples may also activate HIV replication by interacting with the HIV-1 transcription machinery. Herpesvirus immediate early proteins transactivate HIV-1 long terminal repeat (LTR) facilitating HIV replication. HSV-1 immediate early proteins ICP0, ICP4, ICP27, and transactivating proteins IE110 and IE175 induce transactivation of HIV-1 LTR by upregulating NF-kB (Margolis, Rabson, Straus, \& Ostrove, 1992), while EBV EBNA-2 may transactivate HIV-1 LTR in synergy with HIV-1 Tat (Zhang, Guan, Park, et al., 1997), and HHV-8 LANA can also activate HIV LTR (Hyun, Subramanian, Cotter, Thomas, \& Robertson, 2001). Elucidation of the interaction of these factors from the viruses identified in the samples and their impact in OSSN pathogenesis will enhance our knowledge of the molecular processes involved that may lead to the design of therapeutic molecules to block the activated pathways.

Raziuddin et al. found that TNF- $\alpha$ levels are greatly elevated in patients with S. haematobium-induced squamous cell bladder cancer (Raziuddin, Masihuzzaman, Shetty, \& Ibrahim, 1993). Recurrent bacterial urinary tract infections are known to be associated with squamous cell carcinomas of the bladder, even in the absence of concomitant S. haematobium infection (Badawi, 1996). El-Hawey et al. found that 39-66\% of hospitalized patients with schistosomiasis had urinary tract bacterial infections (el Hawey, Massoud, Badr el Din, Waheeb, \& Abd-el Hamid, 1989). Mostafa et al. isolated nitrate-reducing bacteria such as Staphylococcus aureus, Staphylococcus albus, Proteus mirabilis, Klebsiella species and Escherichia coli, from urine samples of $S$. haematobium-infected patients (Mostafa, Helmi, Badawi, Tricker, Spiegelhalder, \& Preussmann, 1994). Habuchi et al. found that $86 \%$ of Egyptian patients with schistosome-associated bladder cancer had p53 mutations in exons 5, 6, 8 and 10 (Habuchi, Takahashi, Yamada, et al., 1993). Badawi noted that as tumor grade increased, so did the p53 mutation rate (Badawi, 1996). Lozano et al. reported that nitric oxide produced by the inflammation from schistosomal egg deposition could cause

p53 mutations through stimulation of endogenous N-nitroso compound generation resulting in DNA alkylation (Lozano, Nakazawa, Cros, Cabral, \& Yamasaki, 1994). We confirmed S. mansoni sequences in our samples, and their contribution to OSSN pathogenesis along with the other infectious agents is intriguing. Studies have shown that acute schistosomiasis increased risk of AIDS virus acquisition possibly through Th2 type immunologic phenotype and increased viral replication in these cells as shown in Kenyan schistosomiasis patients with HIV-1 coinfection producing decreased levels of IL-4 and IL-10 compared to patients with schistosomiasis alone (Mwinzi, Karanja, Colley, Orago, \& Secor, 2001). However, we are not able to predict that the viral and bacterial interactions observed in S. mansoni infections and p53 mutations contributed to OSSN pathogenesis in our cohort.

Malaria whose sequences were also confirmed has been associated with HIV-1 infection and incidence of symptomatic episodes which may be severe or uncomplicated and the corresponding parasite density has been reported to be higher in HIV-1 infected individuals with low CD4 counts (Korenromp, Williams, de Vlas, et al., 2005). Some studies have shown increased viral load with acute malaria and decreased viral load following 
treatment (Barnabas et al., 2011).

Mycobacterium tuberculosis one of the many bacteria whose sequences we identified has been defined as a syndemic (convergence of two or more diseases that act synergistically to magnify the burden of disease) with HIV-1 (Kwan \& Ernst, 2011). HIV-1 causes the depletion of CD4 T cells contributing to susceptibility of coinfected individuals to TB, as this $\mathrm{T}$ cell subset is significant in the control of TB and a majority of HIV-1 infected individuals are now coinfected with TB (Diedrich \& Flynn, 2011).

\section{Conclusion}

Our studies identified sequences from many bacteria, viruses, parasites and fungi in OSSN and pterygia from the HIV-1 infected population suggesting that multiple pathogenic agents may have a role in development of this disease. The interaction between different pathogenic agents and the dysregulatory activities of oncogenic moieties and other antigenic factors in immunocompromised individuals may contribute to oncogenic transformation. The processes, pathways, and levels of interaction of the different pathogen oncogenic moieties in initiating oncogenesis require further studies. Clearly, there is a need to elucidate the molecular processes and pathways involved in pathogenesis of OSSN and pterygia in the HIV population that may lead to development of therapies to control and prevent the diseases. In the Botswana population, it is possible that co infections, the minimal use of parasitic drugs, the innate ability of rapidly evolving organisms to attain resistance to commonly used therapy and the suppression of cell mediated immunity that occurs with AIDS has led to an increase in many common infectious diseases that often act in synergy and may have contributed to the initiation and increased pathogenesis of OSSN.

\section{Acknowledgements}

The authors thank Dr. James Hoxie, Director UPENN CFAR program, Dr. Oathokwa Nkomazana, Dr. Andrew P. Steenhoff, Dr. Rameshwari Thakur, and Ms. Tuelo Baitseng of the Botswana UPENN partnership, Dr. Harvey Friedman, Director Botswana UPENN program, and all participants who provided the samples and contributed to these studies.

\section{References}

Anastos, K., Hoover, D. R., Burk, R. D., et al. (2010). Risk factors for cervical precancer and cancer in HIV-infected, HPV-positive Rwandan women. PLoS One, 5, e13525. http://dx.doi.org/10.1371/journal.pone. 0013525.

Badawi, A. F. (1996). Molecular and genetic events in schistosomiasis-associated human bladder cancer: role of oncogenes and tumor suppressor genes. Cancer Lett, 105, 123-38. http://dx.doi.org/10.1016/0304-3835(96) 04284-X

Barnabas, R. V., Webb, E. L., Weiss, H. A., \& Wasserheit, J. N. (2011). The role of co-infections in HIV epidemic trajectory and positive prevention: a systematic review and meta-analysis. AIDS 2011.

Basti, S., \& Macsai, M. S. (2003). Ocular surface squamous neoplasia: a review. Cornea, 22, 687-704.

Bebell, L. M., Pilcher, C. D., Dorsey, G., et al. (2010). Acute HIV-1 infection is highly prevalent in Ugandan adults with suspected malaria. AIDS, 24, 1945-52. http://dx.doi.org/10.1097/QAD.0b013e32833bb732

Biarc, J., Nguyen, I. S., Pini, A., Gossé, F., et al. (2004). Carcinogenic properties of proteins with pro-inflammatory activity from Streptococcus infantarius (formerly S.bovis). Carcinogenesis, 25(8), 1477-84. http://dx.doi.org/10.1093/carcin/bgh091

Blaser, M. J., Perez-Perez, G. I., Kleanthous, H., Cover, T. L., et al. (1995). Infection with Helicobacter pylori strains possessing cagA is associated with an increased risk of developing adenocarcinoma of the stomach. Cancer Res., 55(10), 2111-5.

Bunnag, D., Cross, J. H., \& Bunnag, T. (2000). LIver Fluke Infections. In: Hunter's Tropical Medicine and Emerging Infectious Diseases. Philadelphia, PA: W.B. Saunders; 2000: 840-6.

Chen, M. G., \& Mott, K. E. (1989). Progress in the assessment of morbidity due to Schistosoma haematobium: A review of the recent literature. Trop Dis Bull, 48, 2643-8.

Crawford, R. J., Hudson, P., Shine, J., Niall, H. D., Eddy, R. L., Shows, T. B. (1984). Two human relaxin genes are on chromosome 9. EMBO J, 3, 2341-5.

Croft, S. L., Sundar, S., \& Fairlamb, A. H. (2006). Drug resistance in leishmaniasis. Clin Microbiol Rev, 19, 111-26. http://dx.doi.org/10.1128/CMR.19.1.111-126.2006 
Diedrich, C. R., \& Flynn, J. L. (2011). HIV-1/mycobacterium tuberculosis coinfection immunology: how does HIV-1 exacerbate tuberculosis? Infect Immun, 79, 1407-17. http://dx.doi.org/10.1128/IAI.01126-10

Dorer, M. S., Fero, J., \& Salama, N. R. (2010). DNA damage triggers genetic exchange in Helicobacter pylori. PLoS Pathog, 6(7). http://dx.doi.org/10.1371/journal.ppat.1001026

el Hawey, A., Massoud, A., Badr el Din, N., Waheeb, A., \& Abd-el Hamid, S. (1989). Bacterial flora in hepatic encephalopathy in bilharzial and non-bilharzial patients. J Egypt Soc Parasitol, 19, 797-804.

Griffin, E., Krantz, E., Selke, S., Huang, M. L., \& Wald, A. (2008). Oral mucosal reactivation rates of herpesviruses among HIV-1 seropositive persons. $J$ Med Virol, 80, 1153-9. http://dx.doi.org/10.1002/jmv.21214.

Guo, X., Hutcheon, A. E., \& Zieske, J. D. (2004). Transduction of functionally active TAT fusion proteins into cornea. Exp Eye Res, 78, 997-1005. http://dx.doi.org/10.1016/j.exer.2003.12.010

Habuchi, T., Takahashi, R., Yamada, H., et al. (1993). Influence of cigarette smoking and schistosomiasis on p53 gene mutation in urothelial cancer. Cancer Res, 53, 3795-9.

Herrera, L. A., \& Ostrosky-Wegman, P. (2001). Do helminths play a role in carcinogenesis? Trends Parasitol, 17, 172-5. http://dx.doi.org/10.1016/S1471-4922(00)01942-5

Hoshikawa, Y., Satoh, Y., Murakami, M., et al. (2002). Evidence of lytic infection of Epstein-Barr virus (EBV) in EBV-positive gastric carcinoma. J Med Virol, 66, 351-9. http://dx.doi.org/10.1002/jmv.2152.

Hyun, T. S., Subramanian, C., Cotter, M. A. 2nd, Thomas, R. A., \& Robertson, E. S. (2001). Latency-associated nuclear antigen encoded by Kaposi's sarcoma-associated herpesvirus interacts with Tat and activates the long terminal repeat of human immunodeficiency virus type 1 in human cells. $J$ Virol, 75, 8761-71. http://dx.doi.org/ 10.1128/JVI.75.18.8761-8771.2001

Kelly, G. L., \& Rickinson, A. B. (2007). Burkitt lymphoma: revisiting the pathogenesis of a virus-associated malignancy. Hematology Am Soc Hematol Educ Program, 277-84. http://dx.doi.org/10.1182/asheducation $-2007.1 .277$.

Kestelyn, P., Stevens, A. M., Ndayambaje, A., Hanssens, M., \& van de Perre, P. (1990). HIV and conjunctival malignancies. Lancet, 336, 51-2.

Kew, M. C. (2003). Synergistic interaction between aflatoxin B1 and hepatitis B virus in hepatocarcinogenesis. Liver Int., 23(6), 405-9. http://dx.doi.org/10.1111/j.1478-3231

Kiire, C. A., \& Dhillon, B. (2006). The aetiology and associations of conjunctival intraepithelial neoplasia. Br J Ophthalmol, 90, 109-13. http://dx.doi.org/10.1136/bjo.2005.077305

Kim, J. M., Lee, J. Y., \& Kim, Y. J. (2008). Inhibition of apoptosis in Bacteroides fragilis enterotoxin-stimulated intestinal epithelial cells through the induction of c-IAP-2. Eur J Immunol, 38(8), 2190-9. http://dx.doi.org/10.1002/eji.200838191

Korenromp, E. L., Williams, B. G., de Vlas, S. J., et al. (2005). Malaria attributable to the HIV-1 epidemic, sub-Saharan Africa. Emerg Infect Dis, 11, 1410-9.

Kullander, J., Forslund, O., \& Dillner, J. (2009). Staphylococcus aureus and squamous cell carcinoma of the skin. Cancer Epidemiol Biomarkers Prev., 18(2), 472-8. http://dx.doi.org/10.1158/1055-9965.EPI-08-0905

Kwan, C. K., \& Ernst, J. D. (2011). HIV and tuberculosis: a deadly human syndemic. Clin Microbiol Rev, 24, 351-76. http://dx.doi.org/10.1128/CMR.00042-10.

Lee, D. S., \& Moss, S. F. (2007). Targeting Helicobacter pylori in gastric carcinogenesis. Expert Opin Ther Targets, 11(6), 757-69. http://dx.doi.org/10.1517/14728222.11.6.757

Lee, G. A., \& Hirst, L. W. (1997). Retrospective study of ocular surface squamous neoplasia. Aust N Z J Ophthalmol, 25, 269-76.

Legros, D., Evans, S., Maiso, F., Enyaru, J. C., \& Mbulamberi, D. (1999). Risk factors for treatment failure after melarsoprol for Trypanosoma brucei gambiense trypanosomiasis in Uganda. Trans R Soc Trop Med Hyg, 93, $439-42$.

Lloyd-Smith, J. O., Poss, M., \& Grenfell, B. T. (2008). HIV-1/parasite co-infection and the emergence of new parasite strains. Parasitology, 135, 795-806. http://dx.doi.org/10.1017/S0031182008000292

Lozano, J. C., Nakazawa, H., Cros, M. P., Cabral, R., \& Yamasaki, H. (1994). G-->A mutations in p53 and 
Ha-ras genes in esophageal papillomas induced by N-nitrosomethylbenzylamine in two strains of rats. Mol Carcinog, 9, 33-9.

Madbouly, K. M., Senagore, A. J., Mukerjee, A., \& Hussien, A. M. (2007). Colorectal cancer in a population with endemic Schistosoma mansoni: is this an at-risk population? Int J Colorectal Dis., 22(2), 175-81. http://dx.doi.org/10.1007/s00384-006-0144-3

Mahomed, A., \& Chetty, R. (2002). Human immunodeficiency virus infection, Bcl-2, p53 protein, and Ki-67 analysis in ocular surface squamous neoplasia. Arch Ophthalmol, 120, 554-8.

Margolis, D. M., Rabson, A. B., Straus, S. E., \& Ostrove, J. M. (1992). Transactivation of the HIV-1 LTR by HSV-1 immediate-early genes. Virology, 186, 788-91.

McDonnell, J. M., McDonnell, P. J., Mounts, P., Wu, T. C., \& Green, W. R. (1986). Demonstration of papillomavirus capsid antigen in human conjunctival neoplasia. Arch Ophthalmol, 104, 1801-5.

Meys, R., Gotch, F. M., \& Bunker, C. B. (2010). Human papillomavirus in the era of highly active antiretroviral therapy for human immunodeficiency virus: an immune reconstitution-associated disease? Br J Dermatol, 162, 6-11. http://dx.doi.org/10.1111/j.1365-2133.2009.09365.x

Mostafa, M. H., Helmi, S., Badawi, A. F., Tricker, A. R., Spiegelhalder, B., \& Preussmann, R. (1994). Nitrate, nitrite and volatile N-nitroso compounds in the urine of Schistosoma haematobium and Schistosoma mansoni infected patients. Carcinogenesis, 15, 619-25. http://dx.doi.org/10.1093/carcin/15.4.619.

Munoz, N., Bosch, F. X., de Sanjose, S., et al. (2003). Epidemiologic classification of human papillomavirus types associated with cervical cancer. $N$ Engl $J$ Med, 348, 518-27.

Mwinzi, P. N., Karanja, D. M., Colley, D. G., Orago, A. S., \& Secor, W. E. (2001). Cellular immune responses of schistosomiasis patients are altered by human immunodeficiency virus type 1 coinfection. J Infect Dis, 184, 488-96. http://dx.doi.org/10.1086/322783.

Palefsky, J. (2009). Human papillomavirus-related disease in people with HIV. Curr Opin HIV AIDS, 4, 52-6. http://dx.doi.org/10.1097/COH.0b013e32831a7246

Peek, R. M. Jr, \& Blaser, M. J. (2002). Helicobacter pylori and gastrointestinal tract adenocarcinomas. Nat Rev Cancer, 2(1), 28-37. http://dx.doi.org/10.1038/nrc703

Peek, R. M. Jr., \& Blaser, M. J. (2002). Helicobacter pylori and gastrointestinal tract adenocarcinomas. Nat Rev Cancer, 2(1), 28-37. http://dx.doi.org/10.1038/nrc703

Puangrat, Y., Somchai, P., \& Helmut, B. (2012). Oxidative and nitrative DNA damage: Key events in opisthorchiasis-induced carcinogenesis. Parasitology International, 61, 130-135. http://dx.doi.org/10.1016/j. parint.2011.06.011

Raziuddin, S., Masihuzzaman, M., Shetty, S., \& Ibrahim, A. (1993). Tumor necrosis factor alpha production in schistosomiasis with carcinoma of urinary bladder. J Clin Immunol, 13, 23-9.

Remeijer, L., Maertzdorf, J., Buitenwerf, J., Osterhaus, A. D., \& Verjans, G. M. (2002). Corneal herpes simplex virus type 1 superinfection in patients with recrudescent herpetic keratitis. Invest Ophthalmol Vis Sci, 43, 358-63.

Rosin, M. P., Anwar, W. A., \& Ward, A. J. (1994). Inflammation, chromosomal instability, and cancer: the schistosomiasis model. Cancer Res, 54(7 Suppl), 1929s-1933s.

Rosin, M. P., Saad el Din Zaki, S., Ward, A. J., \& Anwar, W. A. (1994). Involvement of inflammatory reactions and elevated cell proliferation in the development of bladder cancer in schistosomiasis patients. Mutat Res, 305(2), 283-92.

Ruutu, M., Peitsaro, P., Johansson, B., \& Syrjanen, S. (2002). Transcriptional profiling of a human papillomavirus 33-positive squamous epithelial cell line which acquired a selective growth advantage after viral integration. Int J Cancer, 100, 318-26. http://dx.doi.org/10.1002/ijc.10455

Santoro, M. G., Rossi, A., \& Amici, C. (2003). NF-kappaB and virus infection: who controls whom. EMBO J, 22, 2552-60. http://dx.doi.org/10.1093/emboj/cdg267

Sears, C. L. (2009). Enterotoxigenic Bacteroides fragilis: a rogue among symbiotes. Clin Microbiol Rev, 22(2), 349-69. http://dx.doi.org/10.1128/CMR.00053-08

Simbiri, K. O., Murakami, M., Feldman, M., et al. (2010). Multiple oncogenic viruses identified in Ocular surface squamous neoplasia in HIV-1 patients. Infect Agent Cancer, 5, 6. http://dx.doi.org/10.1186/1750-93 
78-5-6

Spitzer, M. S., Batumba, N. H., Chirambo, T., et al. (2008). Ocular surface squamous neoplasia as the first apparent manifestation of HIV infection in Malawi. Clin Experiment Ophthalmol, 36, $422-5$. http://dx.doi.org/10.1111/j.1442-9071.2008.01794.x

Sriurairatana, S., Tengchaisri, T., \& Sirisinha, S. (1996). Ultrastructural characteristics of liver fluke associated human cholangiocarcinoma cell lines. Southeast Asian J Trop Med Public Health, 27, 57-62.

Srivatanakul, P., Ohshima, H., Khlat, M., Parkin, M. et al. (1991). Opisthorchis viverrini infestation and endogenous nitrosamines as risk factors for cholangiocarcinoma in Thailand. Int J Cancer, 48(6), 821-5.

Verma, N., \& Kearney, J. (1996). Ocular manifestations of AIDS. P N G Med J, 39, 196-9.

Whitley, R. J., Kern, E. R., Chatterjee, S., Chou, J., \& Roizman, B. (1993). Replication, establishment of latency, and induced reactivation of herpes simplex virus gamma 134.5 deletion mutants in rodent models. $J$ Clin Invest, 91, 2837-43. http://dx.doi.org/10.1172/JCI116527

Yang, Y. R., Gray, D. J., Ellis, M. K., Yang, S. K., Craig, P. S., \& McManus, D. P. (2009). Human cases of simultaneous echinococcosis and tuberculosis - significance and extent in China. Parasit Vectors, $2,53$. http://dx.doi.org/10.1186/1756-3305-2-53

Zhang, R. D., Guan, M., Park, Y., et al. (1997). Synergy between human immunodeficiency virus type 1 and Epstein-Barr virus in T lymphoblastoid cell lines. AIDS Res Hum Retroviruses, 13, 161-71. 